\title{
Production of Waterproof Composite Magnesia Cement on the Basis of Local Mineral Resources
}

\author{
Kamila Muzafarovna Gapparova ${ }^{1}$, Tatyana Mikhailovna Khudyakova ${ }^{1}$, Vladimir Fedorovich Verner ${ }^{1} \&$ Lyazzat \\ Shokanovna Atanbayeva \\ ${ }^{1}$ M.Auezov South Kazakhstan State University, Shymkent, Kazakhstan \\ Correspondence: Kamila Muzafarovna Gapparova, M.Auezov South Kazakhstan State University, Shymkent, \\ Kazakhstan. E-mail: cami-shum@mail.ru
}

Received: October 27, 2014

doi:10.5539/mas.v9n3p309

\author{
Accepted: November 8, $2014 \quad$ Online Published: February 28, 2014 \\ URL: http://dx.doi.org/10.5539/mas.v9n3p309
}

\begin{abstract}
The given article contains the research results of the waterproof magnesia cement production on the basis of Kazakhstan mineral resources by the introduction of additives of natural and synthetic wollastonite and calcium hydrosilicate. The input additives promote a considerable consolidation of the magnesia stone's structure and increasing water resistance coefficient from 0,56 to 0,93 . The produced magnesite cement can be used for building of radio-protective constructions, manufacturing plates and panels for internal and external facing of buildings, making seamless floors, garages, car parks, working areas, etc.
\end{abstract}

Keywords: magnesia cement, dolomite, wollastonite, durability, water resistance coefficient

\section{Introduction}

Now the requirement for binding constructional materials is great, and its satisfaction only at the expense of widely applied Portland cement is difficult. In this connection in the low-tonnage housing and agricultural construction it is expedient to use cheaper binding materials, in particular, magnesia and composite magnesia binding agents, received on the basis of local raw materials (Zyryanova V. N. et al., 2010; http://www.premierchemicals.com, 2014).

According to generally accepted ideas, owing to the presence in caustic dolomite of a non-decomposing at low-temperature roasting inert phase $\mathrm{CaCO}_{3}$ which makes $71 \%$ of a total mass of the cementing agent, durability of caustic dolomite is less than durability of caustic magnesite. However, the published currently the research results contain opposite data (Shelikhov et al., 2008).

Also it is known, that at an identical duration of roasting a formed phase, $\mathrm{MgO}$, in dolomite cement has higher activity at hardening than the same phase in caustic magnesite; this fact is confirmed by a smaller size of its crystals (Shelikhov and Rakhimov, 2006). One of the reasons of this effect is the presence in dolomite cement of a non-decomposing at the dolomite's roasting carbonate phase, $\mathrm{CaCO}_{3}$, which can interfere with formation and growth of $\mathrm{MgO}$ crystals owing to epitaxial and endotaxial phenomena which take place at the decomposition of solid substances (Boldyrev, 1997; Prodan, 1986; Sglavo et al., 2011).

An active phase of the dolomite cement is a fine-dispersed magnesium oxide; it has a high surface energy and accordingly, a high reactivity, so magnesium oxide in the dolomite cement by equal conditions of the raw material roasting is more active than magnesium oxide in the caustic magnesite. Therefore using the caustic dolomite for the manufacture of binding materials is more effective than application of the magnesite (Shelikhov \& Rakhimov, 2006).

Tempering magnesium oxide by a magnesium chloride solution raises solubility of $\mathrm{MgO}$ and speeds up the precipitation of jealous $\mathrm{Mg}(\mathrm{OH})_{2}$ from the solution, which further recrystallizes at the simultaneous hardening of all the system. The presence of magnesium chloride, $\mathrm{MgCl}_{2}$, promotes the formation of a complex compound magnesium hydrooxychloride according to the reaction:

$$
5 \mathrm{MgO}+\mathrm{MgCl}_{2}+12 \mathrm{H}_{2} \mathrm{O}=\mathrm{MgCl}_{2} \cdot 5 \mathrm{Mg}(\mathrm{OH})_{2} \cdot 7 \mathrm{H}_{2} \mathrm{O}
$$

The complex salt crystallizes in the form of fibres and needles which play a role of a reinforcing component giving a high durability to the hardened stone (Sulimenko et al., 2001; 
http://www.premiercpg.com/PREMag_MOC.htm, 2014; Bilinski et al., 1984).

At the hydration of the caustic dolomite, containing in it magnesium oxide more full takes part in the formation of new phases in comparison with magnesium oxide in the caustic magnesite. In the case of using the caustic magnesite only a part of magnesium oxide is consumed on the formation of new compounds - magnesium hydrooxychlorides promoting the increasing strength properties of the magnesite stone, other part of the inorganic polymer is applied as a filling component. Thus, in spite of the fact that $\mathrm{MgO}$ content in the caustic magnesite makes $83 \%$, only a part of magnesium oxide will participate in the hydration processes (Kozlova et al., 2009; Li and Chau, 2007; Zhang and Deng, 1995; Deng and Zhang, 1999).

Magnesia cements not only quickly set, but also quickly gain durability: in one day of hardening they have $30-50 \%$ of a standard durability, and in 7 days - already $60-90 \%$ from the durability of 28-daily samples.

Studying of qualitative differences of active phases $(\mathrm{MgO})$ in the dolomite cement and the caustic magnesite after their roasting gives the basis for application of the dolomite instead of the magnesite at the magnesia cements manufacture. Replacement of the magnesite by the dolomite will allow to lower binding materials cost at the expense of decrease of raw material cost and to use local natural resources (Shelikhov et al., 2008).

The most important disadvantage of magnesia cementing agents is a low water resistance coefficient $(0,56)$. There are various ways of increasing water resistance: impregnation by the substances forming protective films on a surface of a material; introduction of polymeric additives in magnesia compositions - synthetic pitches, latex, esters and alcohols; use of the chemical additives promoting formation of insoluble complexes; development of mixed magnesia cements by introduction of active mineral additives, and also natural magnesium hydrosilicates; combination of the above-named methods (Gao et al., 2008; Li et al., 2013; Li et al., 2008).

\section{Experimental Part}

Samples of the dolomite of the Karatau deposit, natural and synthetic wollastonite, calcium hydrosilicate have been selected for the performance of the researches.

Dolomite - is a sedimentary rock containing more $90 \%$ of dolomite. Impurities are calcite and clay minerals. The dolomite chemical composition, mass $\%$ : $\mathrm{MgO}-22,3 ; \mathrm{CaO}-30,1 ; \mathrm{SiO}_{2}-3,80 ; \mathrm{Fe}_{2} \mathrm{O}_{3}-0,68 ; \mathrm{Al}_{2} \mathrm{O}_{3}-0,48$; losses after calcination $-42,64$.

A wollastonite ore of the Verhniy Badam deposit of the South Kazakhstan area, crushed to the full passing through a sieve 008 was used as a natural wollastonite. The wollastonite ore of the given deposit contains, mass $\%$ : wollastonite $-49,4 \%$; calcite $-20,6 \%$; quartz $-20,2 \%$; garnets $-5,1 \%$. The rocks contain inclusions of bismuth, gold, and lead. The chemical composition of the natural wollastonite is the following, mass \%: $\mathrm{SiO}_{2}$ $-50,4 ; \mathrm{CaO}-31,51 ; \mathrm{Al}_{2} \mathrm{O}_{3}-0,3 ; \mathrm{Fe}_{2} \mathrm{O}_{3}-14,87 ; \mathrm{TiO}_{2}-0,15 ; \mathrm{MgO}-0,2 ; \mathrm{Na}_{2} \mathrm{O}-0,87 ; \mathrm{K}_{2} \mathrm{O}-0,3 ; \mathrm{MnO}-0,03$; losses after calcination $-0,02$.

The natural wollastonite is concentrated, is purified from undesirable impurities and accompanying minerals and forms a wollastonite concentrate. The manufacture of wollastonite concentrates provides for using expensive specific methods of crushing and dressing which raise the price of the raw material limiting a field of application of a target product. At the concentration of natural wollastonite ores the transition of the wollastonite in a concentrate makes only 35-49 \%. It is connected with formation of huge dumps of off-grade raw materials. In this connection it is more expedient to use a synthetic wollastonite.

The synthetic wollastonite is a fine-grinded powder obtained on the basis of the granulated slags of the New Dzhambul phosphorus plant, quartz sand and sodium sulphate. A mixture of the components are subjected by a joint dry milling to the residue of $2 \%$ on a sieve 008 with the subsequent wet granulation of the mixture by pelletizing and thermal processing of the pellets at $1000-1050^{\circ} \mathrm{C}$ within $40-60$ minutes. The chemical composition is presented in mass \%: 46,69 $\mathrm{SiO}_{2} ; 43,55 \mathrm{CaO} ; 3,36 \mathrm{MgO} ; 1,26 \mathrm{Al}_{2} \mathrm{O}_{3} ; 0,35 \mathrm{Fe}_{2} \mathrm{O}_{3} ; 1,35 \mathrm{P}_{2} \mathrm{O}_{5} ; 0,09$ $\mathrm{R}_{2} \mathrm{O} ; 2,52 \mathrm{~F} ; 0,87 \mathrm{SO}_{3}$ (Verner et al., 2011).

Synthetic calcium hydrosilicate was produced by the wet milling of a mix of the components (electrothermophosphoric slag + quartz sand + a bleaching additive). The ratio $\mathrm{CaO} / \mathrm{SiO}_{2}$ in the mixture is equal $0,8-0,9$. The product of the wet milling was subjected to the hydrothermal processing in a curing chamber CSU-1m according to a mode 4-6-3 hours at $90^{\circ} \mathrm{C}$. The drying of the obtained product without filtration of a liquid phase was carried out in a drying cabinet at $90-110^{\circ} \mathrm{C}$. The dried product was crushed in a spherical mill to the residue of $2-3 \%$ on a sieve 008 . The chemical composition is the following, mass \%: 46,69 $\mathrm{SiO}_{2} ; 43,55 \mathrm{CaO}$; $3,36 \mathrm{MgO} ; 1,26 \mathrm{Al}_{2} \mathrm{O}_{3} ; 0,35 \mathrm{Fe}_{2} \mathrm{O}_{3} ; 1,35 \mathrm{P}_{2} \mathrm{O}_{5} ; 0,09 \mathrm{R}_{2} \mathrm{O} ; 2,52 \mathrm{~F} ; 0,87 \mathrm{SO}_{3}$. 
The dolomite was roasted in an electric muffle furnace SNOL 12/12 at the temperature $800{ }^{\circ} \mathrm{C}$ within 1 hour. The obtained product was subjected to grinding in a laboratory ball mill to the residue on a sieve 008 no more $15 \%$.

For the studying of basic physical-mechanical properties of the magnesia cement the samples measuring $2 \cdot 2 \cdot 2$ $\mathrm{cm}$ were made from a paste with a normal density. A magnesium chloride water solution in density of $1,25 \mathrm{~g} / \mathrm{cm}^{3}$ in quantity up to $30 \%$ was used for the magnesia cement tempering. The samples consolidated on air at the temperature $20 \pm 5{ }^{\circ} \mathrm{C}$ and relative humidity $65 \pm 5 \%$. Strength tests were carried out at the age of 3, 7, 14 and 28 . Compressive strength is $48-60 \mathrm{MPa}$.

Water resistance of the magnesia stone was estimated according to a softening coefficient which was calculated under a ratio of compressive strength of the samples kept 4 days in water and dry samples: $K_{\text {soft }}=R_{\text {wet }} / R_{\text {dry }}$. The water resistance factor is 0,56 .

\section{Results}

Magnesia cement is an air binding agent; therefore the development of waterproof composite magnesia cement has a special urgency.

The fulfilled experiments allow establishing that from the point of view of efficiency and economic reasonability the most perspective way of increasing water resistance of the magnesia cement is its modification by various fine-dispersed mineral additives.

For the obtaining of compositions on the magnesia cement basis, the caustic dolomite was mixed with the crushed additives in number of 5-30\%. After the air hardening compressive strength of the samples at the age of $3,7,14$ and 28 days was determined. Optimum quantity of the additives has been chosen as a result of the carrying out of the experiments $-15 \%$ and $20 \%$.

Water resistance coefficient for the composite magnesia cements is $0,75-0,93$.

The results of physical-mechanical tests of the composite magnesia cements are represented in Figure 1 and 2.

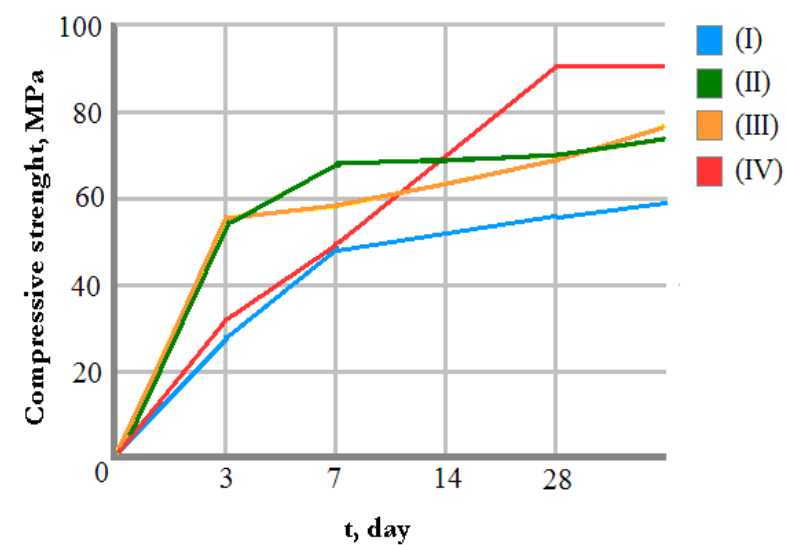

Figure 1. Kinetics of increase in durability of the samples hardening within 3 days, 7 days, 14 days and 28 days

I - magnesia cement; II - magnesia cement with the natural wollastonite $(15 \%)$; III - magnesia cement with the synthetic wollastonite (15\%); IV - magnesia cement with the calcium hydrosilicate $(15 \%)$.

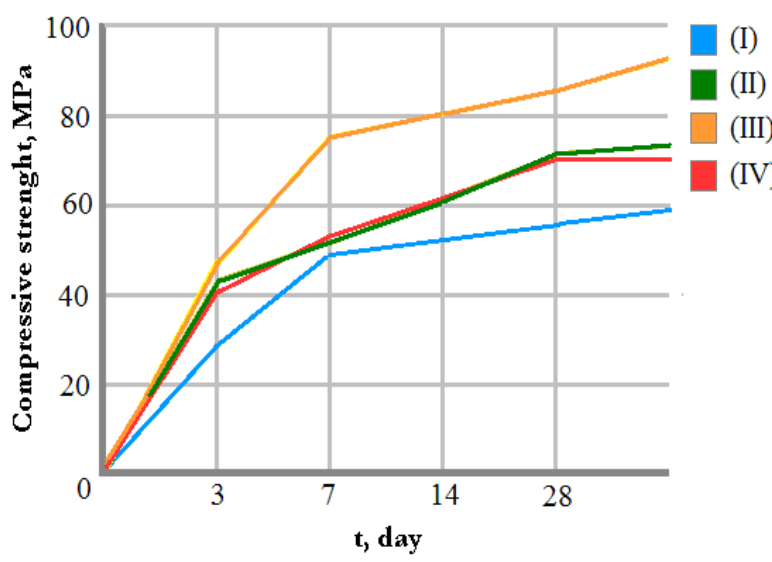

Figure 2. Kinetics of increase in durability of the samples hardening within 3 days, 7 days, 14 days and 28 days

I - magnesia cement; II - magnesia cement with the natural wollastonite $(20 \%)$; III - magnesia cement with the synthetic wollastonite (20\%); IV - magnesia cement with the calcium hydrosilicate (20\%).

The produced composite magnesia cement contains three basic structural units which define its mechanical durability: particles of solid filler, binding substance and a contact zone between them. Destruction, as a rule, occurs on the weakest structural units. At addition of mineral filler the energy effect of its surface extends both on the contact zone and on the binding substance. In magnesia cements the filler's chemical composition and energy effect of a surface of its particles influence on the development of hydration process. Energy of the mineral filler's crystal lattice defines such properties as mechanical durability, thermal stability, ability to dissolution in water, interaction with a cementing agent (Zyryanova et al., 2010).

According to the results of the X-ray phase analysis of the samples at the age of 28 days, the basic phases of 
oxyhydrochloride magnesia stone are magnesium hydroxide, $\operatorname{Mg}(\mathrm{OH})_{2}$ with $\mathrm{d} / \mathrm{n}=4,77 ; 2,37 ; 1,79 ; 1,57 \AA$; magnesium pentaoxyhydrochloride $\left(5 \mathrm{MgO} \cdot \mathrm{MgCl}_{2} \cdot 13 \mathrm{H}_{2} \mathrm{O}\right)$ with $\mathrm{d} / \mathrm{n}=7,7 ; 4,17 ; 1,97 \AA$; magnesium trioxyhydrochloride $\left(3 \mathrm{MgO} \cdot \mathrm{MgCl}_{2} \cdot 11 \mathrm{H}_{2} \mathrm{O}\right)$ with $\mathrm{d} / \mathrm{n}=8,3 ; 3,88 ; 2,46 \AA$; calcium carbonate $\left(\mathrm{CaCO}_{3}\right)$ with d/n = 3,$038 ; 2,495 ; 1,908 ; 1,871 \AA$.

Data of the electron microscopy (a scanning electron microscope JSM-6490LV, JEOL, JAPAN) of the investigated samples have confirmed the received data concerning the phase composition of the hardened stone and features of its structure. Microphotographies of a chip of the magnesia stone tempered by the magnesium chloride solution in density of $1,25 \mathrm{~g} / \mathrm{cm}^{3}$ at the age of 28 days are represented in Figure 3.
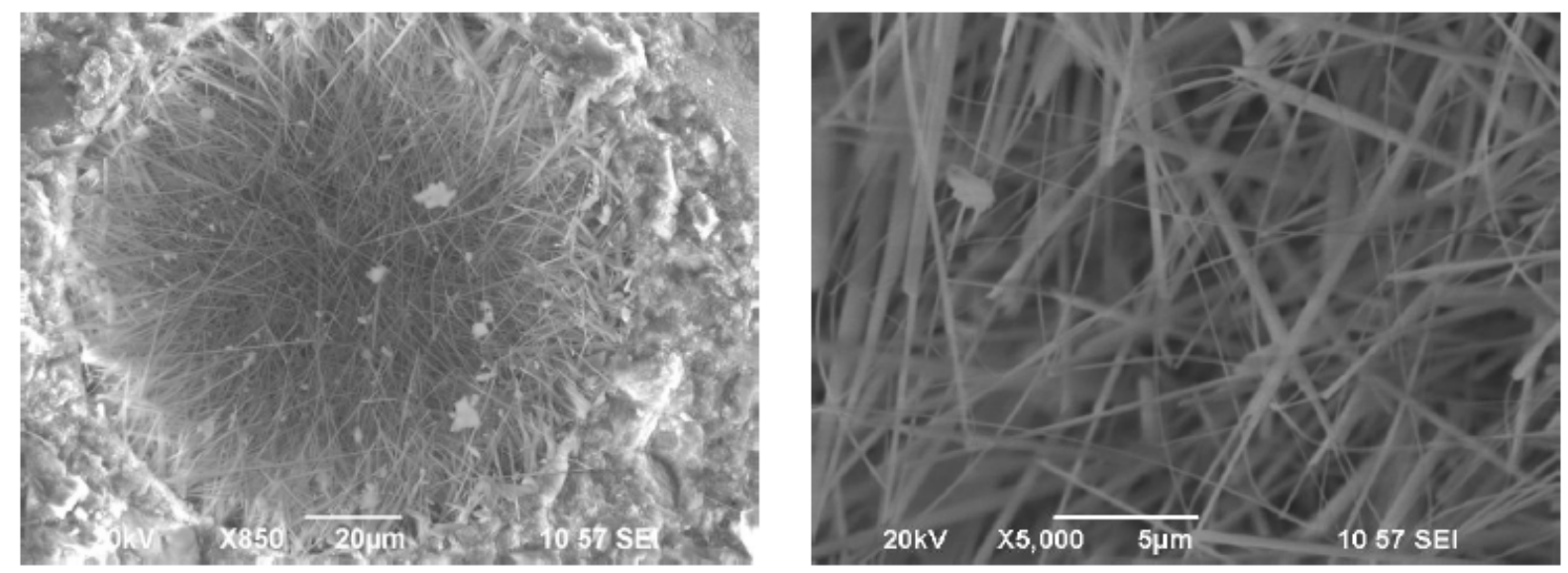

Figure 3. Microphotographies of structures characteristic for the magnesia cement obtained on the basis of the caustic dolomite

The products of the magnesia cement hardening are mainly magnesium hydrooxychlorides. A great bulk of new formations of the stone is well generated columnar and plane-prismatic crystals of magnesium penta- and trioxyhydrochlorides. In cavities and cells in the size 100 microns and less, the needle crystals are formed on an internal surface of the cells, forming a continuous layer of small needles. Their size reaches $0,10-0,13$ microns. Such the crystallization is a characteristic for the majority of micropores in which a free volume is filled with the crystals of oxychloride phases, or the formed crystals cover with a continuous layer an internal surface of the cells. The presence of calcium carbonate intensifies formation and crystallization of the hydrooxychloride phases in all the volume and in the interior of the pores that provides increase of the stone density and durability (Figure 4) (Khudyakova et al., 2013).

In addition the research results have shown (Figure4), that the structure of the hardened stone of the composite magnesia cement with silicate components almost doesn't contain pores. Cells between particles are filled by the new formations of the needle and lamellar form. The dense, practically nonporous structure of the hardening products can provide insignificant water absorption of the hardened magnesia stone.

The using both natural and synthetic wollastonite, and also calcium hydrosilicate as additives promotes the formation in the magnesia cement stone at the hardening of low-basic calcium hydrosilicates which crystals have a fibrous structure. 

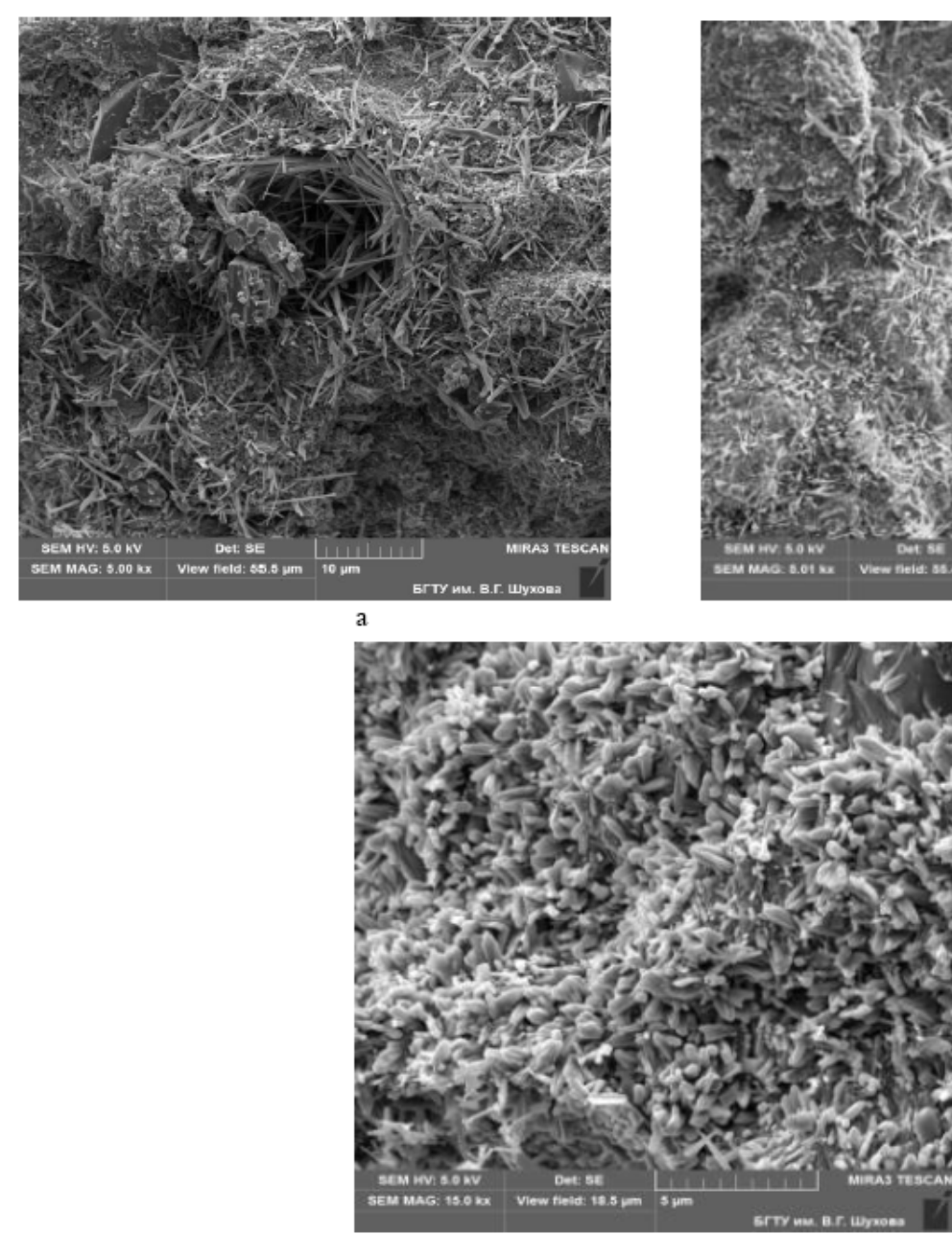

c

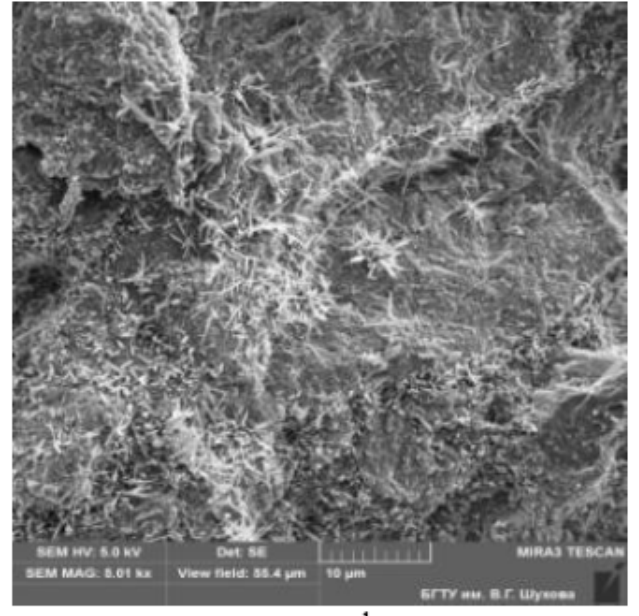

b

Figure 4. Microphotographies of chips of the hardened magnesia stone with the additives

a) with the natural wollastonite additive; b) with the synthetic wollastonite additive; c) with the hydrosilicate additive.

Water resistance and durability of any material are always connected with its apparent porosity determined according to water absorption. Therefore the research of additives' influence on apparent porosity of a magnesia stone gives additional data concerning a structure of the formed material and its behaviour at operation.

Water absorption of a free-additive magnesia stone defined by a technique (Butt and Timashev, 1973) makes $14 \%$; the addition of optimum amounts of investigated additives lead to decrease of its water absorption to $7-8 \%$. Water absorption of the hardened mixes at the water saturation within 48 hours at full immersing of the samples in water should not exceed $8 \%$ mass. Water absorption of the same samples at capillary suction effect within 24 hours should not exceed $6 \%$ mass. At such apparent porosity a magnesia stone has a high water resistance. Determination of this indicator by the air filtration method has shown that a water resistance indicator for the modified water-resistance magnesia stone is W12-14.

Differentially thermal research allows marking out the endothermic effects corresponding to certain phases of phasic dehydration and decomposition of the hydration products. All phase transformations occur only with heat absorption. And, depending on a chemical composition, temperatures of the decomposition of initial and intermediate products fluctuate in rather wide interval.

Thermograms with microreinforcing additives testify to the generality of magnesia oxyhydrochloride base and show the affinity of properties of structureless new formations. At the similarity of appearance of the magnesia stone's thermograms the interpretation of individual endothermic effects is various. 


\section{Discussion}

The increase of mechanical durability of the products of the hardening the investigated compositions is the reason for a high durability of adherence of the cementing material with the silicate components and microreinforcing the structure.

At the introduction of 15 and $20 \%$ of the natural wollastonite the durability of the magnesia stone exceeds the durability of the magnesia cement without the additives at the age of 7 days on $37 \%$ and $4 \%$ accordingly, at the age of 28 days - on $34 \%$ and $28 \%$; at the addition of the synthetic wollastonite: at the age of 7 days - on $19 \%$ and $54 \%$, at the age of 28 days - on $23 \%$ and $49 \%$; at the using the calcium hydrosilicate: at the age of 7 days on $2 \%$ and $8 \%$, at the age of 28 days - on $64 \%$ and $22 \%$.

A positive influence of the fillers on mechanical durability of the composite materials can be caused the inhibition of formation of microcracks and the structure reinforcing at the needle form of particles of the filler, therefore it is important to determine an optimum concentration of the filler and to prefer a material with the needle form of particles. The microconglomeratic structure of the stone of the composite binding agent is formed on the basis of an aggregate of the crystals of magnesium hydrooxychlorides and particles of minerals.

\section{Conclusion}

Previously fulfilled researches connecting to the development of technological process of a magnesia cement production from dolomite have allowed to establish that depending on a mode of the roasting natural dolomite, the tempering caustic dolomite, nature of the tempering substances a cementing agent can be produced which isn't inferior to caustic magnesite in the respect of basic physicomechanical properties. It has been shown, that the tempering caustic dolomite by a magnesium chloride solution of reactive qualification and a bischofite solution, having various contents of sodium and potassium chlorides in them, make essential impact on bonding properties of the produced cement. In this connection the supposition has been made that alkaline metals' chlorides are strong modifiers for the magnesium chloride tempering agent. The literature analysis has shown that in the works devoted to studying of processes of a magnesia cement tempering the influence of a tempering agent's impurity was studied insufficiently.

In connection with this fact, our further researches will be connected with the determination of influence of sodium and potassium chlorides and sulphates in a magnesium chloride solution on a tempering process, a structure and basic physicomechanical properties of magnesia cement. Also, in connection with the insufficient level of studying of interaction of hydration products of a magnesia cement on the basis of dolomite with various mineral fillers the further research will study in detail a contact zone on the interface between the fillers and hydration products of the cementing substance as the contact zone can be various depending on surface energy of a substance, $\mathrm{pH}$ of surfaces of the used fillers and conditions of the contact formation. According to the research results the manufacture of experimental-industrial samples of composite magnesia cements and products on their basis is planned. At the present time in the research institute "Building materials, construction and architecture" the assembly of equipment and installation of a shaft furnace for the roasting graded dolomite crushed stone is carried out.

\section{Acknowledgments}

Authors would like to thank Ministry of Education and Science of the Republic of Kazakhstan and contract manager "Energy-saving technology of low-temperature binding materials of special purpose".

\section{References}

Bilinski, H., Matkovic, B., \& Mazuranic, C. (1984). The formation of magnesium oxychloride phases in the systems $\mathrm{MgO}-\mathrm{MgCl}_{2}-\mathrm{H}_{2} \mathrm{O}$ and $\mathrm{NaOH}-\mathrm{MgCl}_{2}-\mathrm{H}_{2} \mathrm{O}$. Journal of the American Ceramic Society, 67(4), 266-269. http://dx.doi.org/10.1111/j.1151-2916.1984.tb18844.x

Boldyrev, V. (1997). Reactivity of solid substances. Novosibirsk: The Russian Academy of Sciences.

Butt, Y. M., \& Timashev, V. V. (1973). Workshop on chemical technology of binders. Moscow: Graduate School.

Deng, D., \& Zhang, C. (1999). The formation mechanism of the hydrate phases in magnesium oxychloride cement. Cement and Concrete Research, 29(9), 1365-1371. http://dx.doi.org/10.1016/S0008-8846(98)00247-6

Gao, P. W., Lu, X. L., Geng, F., Li, X. Y., Hou, J., Lin, H., \& Shi, N. N. (2008). Production of MgO-type expansive agent in dam concrete by use of industrial by-products. Building and Environment, 43(4), 453-457. http://dx.doi.org/10.1016/j.buildenv.2007.01.037

Khudyakova, T. M. (2013). Energy-saving technology of low-temperature binding materials of special purpose, 
Shymkent, Kazakhstan.

Kozlova, V. K., Manoha, A. M., Sutula, I. G., \& Gushchina, E. N. (2009). Influence of a roasting temperature on properties of magnesia binding agents. Building materials, 7, 56-58.

Kuzmenkov, M. I., Marchik, E. V., \& Starodubenko, N. G. (2007). Magnesia cement from local raw materials. Proceedings BSTU Conceptual Problems, 15, 51-53.

Li, J. Q., Li, G. Z., \& Yu, Y. Z. (2008). The influence of compound additive on magnesium oxychloride cement/urban refuse floor tile. Construction and Building Materials, 22(4), 521-525. http://dx.doi.org/10.1016/j.conbuildmat.2006.11.010

Li, Y., Yu, H. F., Zheng, L. A., Wen, J. W., Cheng, Y., \& Tan, Y. S. (2013). Compressive strength of fly ash magnesium oxychloride cement containing granite wastes. Construction and Building Materials, 38, 1-7. http://dx.doi.org/10.1016/j.conbuildmat.2012.06.016

Li, Z. J., \& Chau, C. K. (2007). Influence of molar ratios on properties of magnesium oxychloride cement. Cement and Concrete Research, 37(6), 866-870. http://dx.doi.org/10.1016/j.cemconres.2007.03.015

MAGOX®. (n.d.). Magnesium Oxide \& Magnesium Hydroxide: Premier Magnesia, LLC. Retrieved March 15, 2014, from http://www.premierchemicals.com

Nosov, A. V., Chernykh, T. N., \& Kramar, L. Y. (2014). Features of the interaction of hydration products dolomite magnesium oxychloride cement with fillers of different genesis. Technique and technology of silicates, 21(2), 2-7.

Prodan, E. A. (1986). Inorganic topochemistry. Minsk: Science and technics.

Products | PREMag MOC ${ }^{\circ}$ | Magnesium Oxychloride Cements. (n.d.). Products | PREMag MOC $\mathbb{R} \mid$ Magnesium Oxychloride Cements. Retrieved March 20, 2014 from http://www.premiercpg.com/PREMag_MOC.html

Sglavo, V. M., Genua, F. D., Conci, A., Ceccato, R., \& Cavallini, R. (2011). Influence of Curing Temperature on the Evolution of Magnesium Oxychloride Cement. Journal of Materials Science, 46(20), 6726-6733.

Shelikhov, N. S., Rakhimov, R. Z. (2006). Complex using carbonate raw materials for the building materials manufacture. Building materials, 9, 42.

Shelikhov, N. S., Rakhimov, R. Z., \& Morozov, V. P. (2008). Features of formation of an active phase MgO in dolomite cement. Building materials, 11, 32 .

Sulimenko, L. M., Savelyev, V. G., \& Tikhomirova, Sh. N. (2001). Principles of the binding material technology. Moscow: Russian Chemical Technological University named after D. I. Mendeleyev.

Verner, V. F., Bishimbaev, V. K., Khudyakova, T. M., \& Gapparova, K. M. (2011). Method of fine-dispersed wollastonite production. Patent 25064 RK.

Zhang, C., \& Deng, D. (1995). Research on the water resistance of magnesium oxychloride cement and its improvement. Journal of the Chinese Ceramic Society, 6, 673-679.

Zyryanova, V. N., Lytkina, Ye. V., \& Berdov, G. I. (2010). Improvement of the mechanical strength and water resistance of magnesia binders substances the introduction of mineral fillers. Proceedings of the higher educational institutions, 11, 21-26.

Zyryanova, V. N., Lytkina, Ye. V., \& Berdov, G. I. (2010). Influence of mineral fillers on the properties of magnesia binders. Technique and Technology of Silicates, 2, 2-6.

\section{Copyrights}

Copyright for this article is retained by the author(s), with first publication rights granted to the journal.

This is an open-access article distributed under the terms and conditions of the Creative Commons Attribution license (http://creativecommons.org/licenses/by/3.0/). 